\title{
PARIWISATA PUSAKA: DESTINASI DAN MOTIVASI WISATA DI PUSAKA SAUJANA IMOGIRI YOGYAKARTA
}

\author{
Fitria Puspita Rani ${ }^{1}$ \\ Hanson E. Kusuma ${ }^{2}$ \\ Athina Ardhyanto ${ }^{2}$ \\ ${ }^{1}$ Program Studi Magister Rancang Kota Institut Teknologi Bandung; \\ ${ }^{2}$ Sekolah Arsitektur Perencanaan dan Pengembangan Kebijakan, Institut Teknologi Bandung. \\ Penulis Korespondensi e-mail : fitriapuspitarani@gmail.com
}

\begin{abstract}
Imogiri area is an area that has an important role in the history of the city of Yogyakarta. Imogiri is a Saujana Heritage Area because it has the potential of nature heritage and cultural heritage. Through several studies entering into strategic areas to get priority in the development, especially the development of heritage tourism. The purpose of this study is to find tourist destinations in Imogiri the most popular and the motivation of tourist visits. The study used qualitative methods with data collection through online surveys in the form of questionnaires. From the results of the analysis found that the most popular destination by visitors is a natural tourist attractions, while the main motivation of the visit is the desire of tourists to perform recreational activities. The results of this study can be useful in determining the priority and space program required in the development of heritage tourism in Imogiri Area.

Keywords: Cultural Landscape, Imogiri, Heritage Tourism, Yogyakarta.
\end{abstract}

\begin{abstract}
ABSTRAK
Kawasan Imogiri adalah sebuah kawasan yang memiliki peran penting dalam perjalanan sejarah Kota Yogyakarta. Imogiri merupakan Kawasan Pusaka Saujana karena memiliki potensi pusaka alam dan pusaka budaya. Melalui beberapa kajian masuk dalam kawasan strategis sehingga mendapat prioritas dalam pengembangannya, khususnya pengembangan pariwisata pusaka. Tujuan dari penelitian ini adalah menemukan destinasi wisata di Imogiri yang paling banyak diminati serta motivasi kunjungan wisatawan. Penelitian menggunakan metode kualitatif dengan pengumpulan data melalui survei online dalam bentuk kuesioner. Dari hasil analisis ditemukan bahwa destinasi yang paling diminati oleh pengunjung adalah tempat wisata alam, sedangkan motivasi kunjungan yang utama adalah keinginan wisatawan untuk melakukan kegiatan rekreasi. Hasil dari penelitian ini bermanfaat dalam menentukan prioritas serta merumuskan program ruang yang diperlukan dalam pengembangan pariwisata pusaka di Kawasan Imogiri.

Kata Kunci: Imogiri, Pariwisata Pusaka, Pusaka Saujana, Yogyakarta
\end{abstract}




\section{PENDAHULUAN}

Yogyakarta merupakan salah satu tempat di Indonesia yang dapat dijadikan sebagai tempat pilihan untuk berwisata atau rekreasi keluarga. Alasan Yogyakarta pantas untuk menjadi salah satu tempat pilihan untuk berwisata adalah mempunyai objek wisata yang beraneka ragam mulai dari wisata tentang budaya sampai pemandangan alam, kerajinankerajinan Yogyakarta yang beraneka ragam dapat dijadikan sebagai buah tangan oleh para pengunjung atau wisatawan, didukung dengan industri yang mendukung kemajuan wisata di Yogyakarta serta Sumber Daya Manusia yang berkualitas. Selain itu, sejarah Yogyakarta juga mampu menjadikan daya tarik wisatawan untuk memilih Yogyakarta sebagai destinasi tempat wisata (Atma, 2016).

Kota Yogyakarta tentu tidak akan lepas dari kawasan Imogiri, kawasan yang yang terletak di sisi tenggara Yogyakarta ini dikenal sebagai tempat beradanya makam Raja Mataram. Dengan nilai sejarah yang tinggi bagi perkembangan Kota Yogyakarta,Imogiri ditetapkan sebagai Kawasan Cagar Budaya melalui Penetapan Gubernur Nomor 186 Tahun 2011. Kini, Imogiri juga dikenal sebagai sentra penghasil batik serta kawasan dengan panorama perbukitan yang menjadikannya salah satu destinasi wisata alam di Yogyakarta.

Sebagai upaya pelestarian, telah dilakukan beberapa kajian guna mengiringi perencanaan di kawasan Imogiri. Arah pelestarian untuk kawasan ini adalah perlindungan, pengembangan dan pemanfaatan sebagai permukiman kreatif yang terintegrasi dengan alam dan dapat menjadi atraksi wisata dan edukasi (Rencana Induk Kawasan Budaya Perkotaan Yogyakarta 2014-2034). Imogiri juga dinilai memiliki peluang menjadi kawasan perdesaan yang memiliki nilai saujana dan nilai ekonomi Kreatif Lokal dan direncanakan menjadi Ecomuseum Batik (Rencana Terpadu dan Jangka Menengah Kawasan Strategis Keistimewaan, 2016). Dalam kajian tersebut juga disebutkan bahwa penelitian lanjutan yang dapat mendukung perkembangan di Pusaka Saujana Imogiri perlu dilakukan.

Tujuan dari penelitian ini adalah menemukan lokasi yang paling diminati wisatawan saat mengunjungi Pusaka Saujana Imogiri serta alasannya. Tempat-tempat yang mendapat penilaian dominan dapat menjadi prioritas dalam pelaksanaan program peningkatan fisik, sarana prasarana dan promosi. Sedangkan alasan berkunjung yang diberikan oleh responden dapat menjadi informasi untuk mengetahui faktor-faktor yang membuat seseorang tertarik dan termotivasi untuk mengunjungi objek tertentu di Pusaka Saujana Imogiri. 
Dalam Piagam Pelestarian Pusaka Indonesia 2003 dijelaskan bahwa Pusaka Saujana merupakan gabungan pusaka alam dan pusaka budaya dalam kesatuan ruang dan waktu. Pusaka alam adalah bentukan alam yang istimewa sementara pusaka budaya adalah hasil cipta, rasa, dan karya yang istimewa dari lebih 500 suku bangsa di Tanah Air Indonesia, dan dalam interaksinya dengan budaya lain sepanjang sejarah keberadaannya (JPPI \& ICOMOS, 2003). Pusaka saujana mengkaji perihal identitas, bagaimana mempertahankan dasar-dasar keterampilan dan pengetahuan tradisional dalam menghadapi globalisasi dan teknologi baru (Taylor \& Lennon, 2012)

Kegiatan pariwisata pada kawasan pusaka saujana saat ini telah banyak dilakukan dengan memanfaatkan alam Indonesia yang indah dan budaya yang hidup bersamanya. Kedua objek tersebut menjadi daya tarik bagi berkunjung. Cahyadi (2009) menuturkan bahwa pariwisata pusaka pada suatu pusaka saujana menyatukan kegiatan pendidikan, pelestarian budaya dan alam serta aktifitas ekonomi sehingga kekhawatiran akan kerusakan alam dan budaya dapat dihindari karena potensi alam dan budaya menjadi atraksi utama yang tidak akan dieksploitasi namun justru dipelihara.

Imogiri merupakan sebuah pusaka saujana karena memiliki perpaduan antara kekayaan alam dan budaya buatan manusia. Sebagai sebuah Pusaka Saujana, Imogiri memiliki beberapa potensi yang dituangkan dalam enam nilai keunggulan (Rencana Terpadu dan Jangka Menengah Kawasan Strategis Keistimewaan 2016), yaitu:

1. Keunggulan Mahakarya Ekologi, terlihat pada kelestarian alam dan keindahan lanskapnya

2. Keunggulan Mahakarya Kepurbakalaan, terlihat pada banyaknya bangunan dan situs cagar budaya

3. Keunggulan Filosofi, terlihat pada keberadaan Makam Raja-raja Mataram yang memiliki nilai filosofi bagi Kota Yogyakarta

4. Keunggulan Mahakarya Seni Tradisi dan Kontemporer, berupa lestarinya tradisi Jawa, sentra batik, keris dan wayang kulit

5. Keunggulan Kerakyatan/Komunitas Kampung/Desa dan Anak Muda, dengan adanya kelompok sadar wisata, kelompok perajin, desa wisata dan desa budaya

6. Keunggulan Sistem Budaya Pertanian, terlihat pada lahan pertanian yang membentang sejauh mata memandang. 
Kegiatan pariwisata di Pusaka Saujana Imogiri telah lama berlangsung dan untuk menjaga kelestariannya telah disusun seperangkat regulasi untuk menjadi arahan dalam pemanfaatannya, antara lain PERDAIS 2 tahun 2017 tentang Tata Ruang Tanah Kasultanan dan Tanah Kadipaten. Tertulis bahwa pemanfaatan Satuan Ruang Strategis Makam Raja-Raja di Imogiri meliputi zona inti dan zona penyangga. Pemanfaatan pada zona inti harus mengikuti prinsip pelestarian cagar budaya, sedangkan pada zona penyangga fasilitas penunjang kegiatan wisata dapat dilakuakn dengan syarat tidak berpotensi merusak kawasan cagar budaya dan ilmu pengetahuan.

Terdapat dua faktor yang memotivasi wisatawan untuk melakukan perjalanan wisata, yaitu faktor pendorong dan faktor penarik. Faktor pendorong merupakan motivasi yang berasal dari dalam diri seseorang, misalnya keinginan untuk melepaskan kejenuhan dari pekerjaan sehari-hari, melakukan interaksi sosial dengan masyarakat, alam dan budaya, serta sebagai bentuk aktualisasi diri. Sedangkan faktor penarik adalah motivasi yang berasal dari kondisi daya tarik dan fasilitas di tujuan wisata (Keliwar, 2015).

Sedangkan Uysal dan Hagan (dalam Sahara, 2016) menyebutkan ada lima faktor yang dapat menarik wisatawan untuk datang ke daerah tujuan wisata, yaitu atraksi (1) atraksi alam dan sejarah, (2) kuliner, (3) masyarakat, (4) fasilitas rekreasi, dan (5) citra dari destinasi yang ditawarkan.

Faktor lain yang menjadi motivasi seseorang untuk melakukan perjalanan wisata (Dwiputra, 2010 ) antara lain:

1. Physical or physiological motivation (motivasi yang bersifat fisik atau fisiologis), antara lain untuk relaksasi, kesehatan, kenyamanan, berpartisipasi dalam kegiatan olah raga, bersantai, dan sebagainya.

2. Cultural motivation (motivasi budaya), yaitu keinginan untuk mengetahui budaya, adat, tradisi, dan kesenian daerah lain. Termasuk juga ketertarikan akan berbagai obyek tinggalan budaya (monumen bersejarah)

3. Social motivation atau interpersonal motivation (motivasi yang bersifat sosial), seperti mengunjungi teman dan keluarga, menemui mitra kerja, ziarah, pelarian dari situasi yang membosankan, dan sebagainya. 
4. Fantasy motivation (motivasi karena fantasi), fantasi bahwa di daerah lain seseorang akan bisa lepas dari rutinitas keseharian yang menjemukan, dan ego-enhancement yang memberikan kepuasan psikologis.

\section{METODOLOGI}

Penelitian ini dilaksanakan menggunakan metode penelitian kualitatif (Creswell, 2008) yang bersifat eksploratif (Groat \& Wang, 2002). Penelitian kualitatif eksploratif bertujuan untuk mendapat data berupa informasi mengenai tempat-tempat yang paling ingin dikunjungi wisatawan saat mendatangi Pusaka Saujana Imogiri serta alasan yang menjadi pertimbangan pengunjung dalam berwisata.

Metode pengumpulan data menggunakan survei dalam bentuk kuesioner online. Jumlah responden yang diperoleh sebanyak 83 orang dari berbagai kota di Indonesia dengan beragam latar belakang profesi. Survei bersifat terbuka untuk responden yang sudah pernah maupun yang belum pernah mengunjungi Imogiri.

Kuesioner online berisi pertanyaan yang disusun secara kualitatif dan kuantitatif (mixmethod). Pertanyaan kuantitatif dengan pertanyaan tertutup (close-ended), sedangkan pertanyaan kualitatif menggunakan struktur pertanyaan terbuka (open-ended). Pertanyaan kuantitatif berisi data diri responden yang meliputi jenis kelamin, usia, pekerjaan, dan daerah asal.

Pertanyaan tertutup juga digunakan untuk menanyakan tempat yang ingin dikunjungi di Imogiri. Setiap responden dapat memilih lebih dari satu destinasi yang diminati. Pertanyaan berisi beberapa pilihan destinasi yang dianggap mewakili nilai-nilai keunggulan kawasan serta beberapa gambar yang pada destinasi tersebut. Destinasi ini meliputi:

1. Makam Raja Mataram (mewakili Nilai Keunggulan Mahakarya Kepurbakalaan dan Nilai Keunggulan Filosofi)
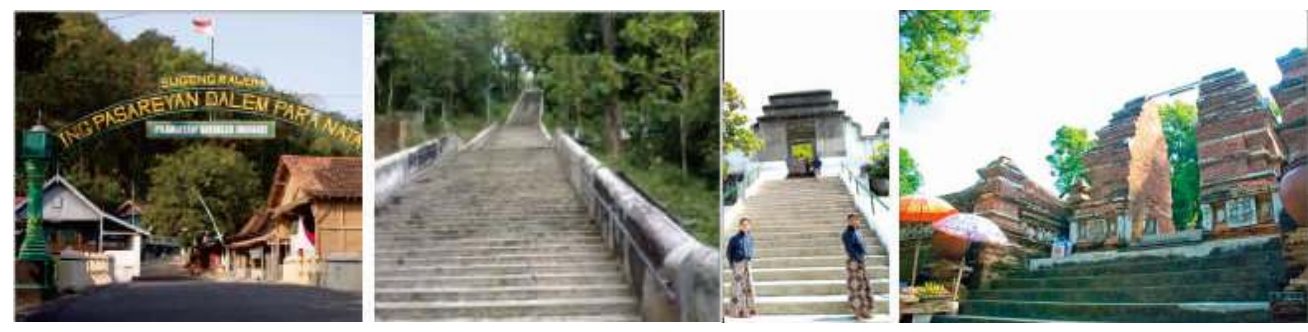

Gambar 1. Makam Raja Mataram

Sumber: Dokumentasi Penulis, 2016 
2. Tempat Wisata Alam (mewakili Nilai Keunggulan Ekologi dan Nilai Keunggulan Pertanian)
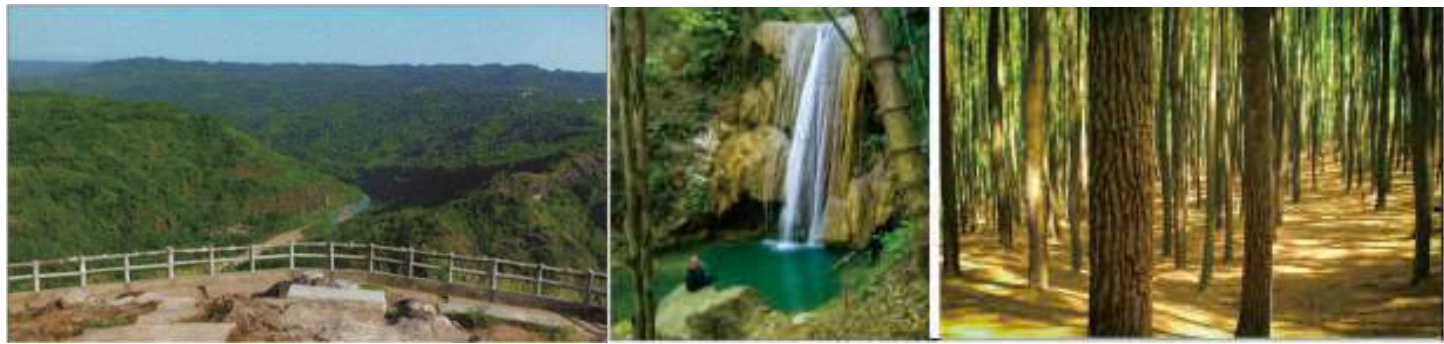

Gambar 2. Kebun Buah Mangunan, Hutan Pinus dan Air Terjun Sumber: https://www.sobatjogja.com

3. Sentra Kerajinan (mewakili Nilai Keunggulan Seni Tradisi dan Nilai Keunggulan Kerakyatan)

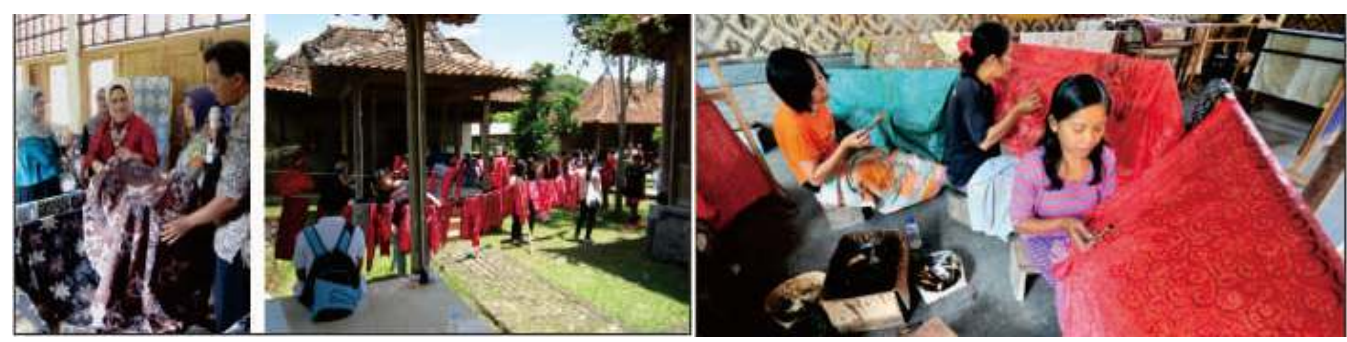

Gambar 3. Pembuatan, Pameran dan Workshop Batik Sumber: https://travel.kompas.com

4. Bangunan Tradisional Jawa (mewakili Nilai Keunggulan Mahakarya Kepurbakalaan dan Nilai Keunggulan Seni Tradisi)
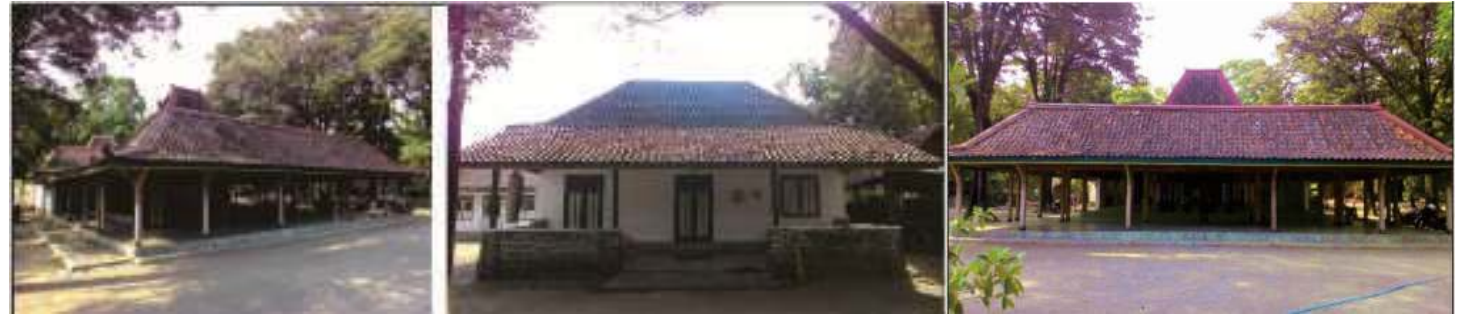

Gambar 4. Dalem Bupati Puroloyo

Sumber: http://arsip.tembi.net

5. Rumah Penduduk/Arsitektur Vernakular (mewakili Nilai Keunggulan Seni Tradisi dan Nilai Keunggulan Kerakyatan) 


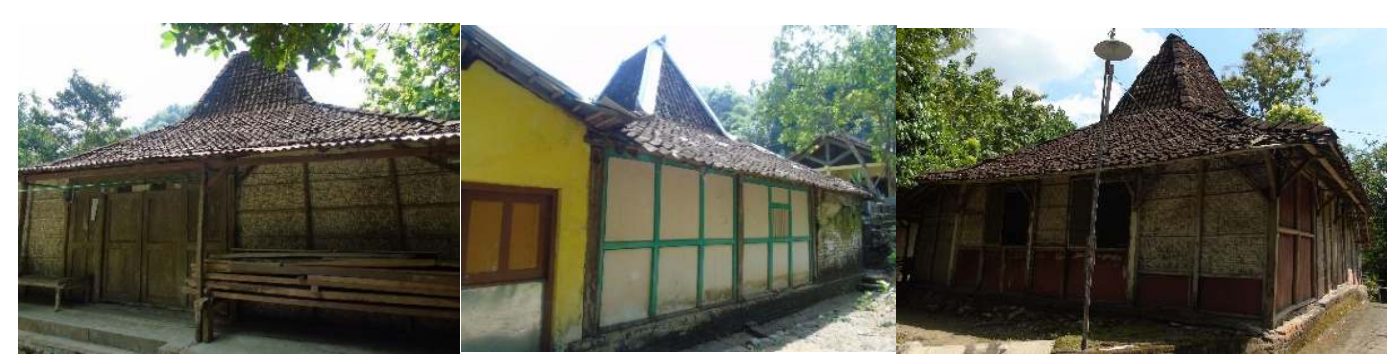

Gambar 5. Rumah Penduduk di Imogiri

Sumber: Guide Book of International Summer Course on Imogiri Saujana Heritage, 2016

6. Tempat Kuliner (mewakili Nilai Keunggulan Seni Tradisi)

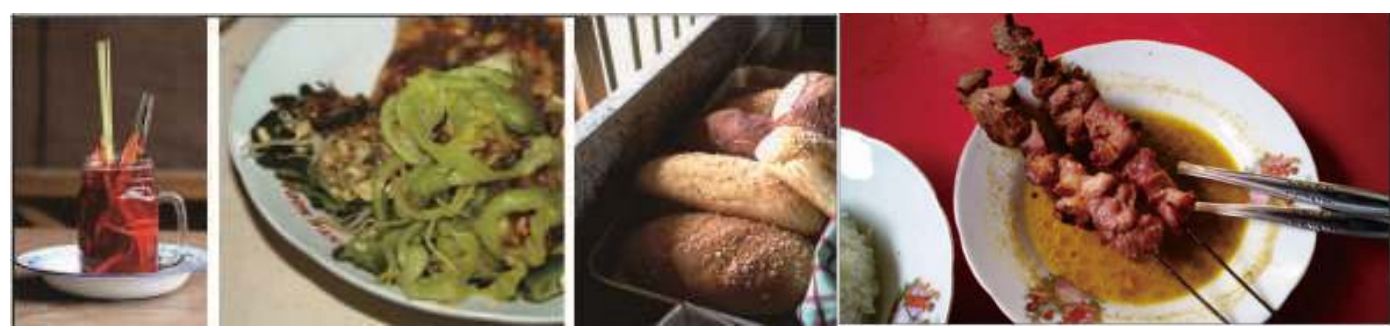

Gambar 6. Wedang Uwuh, Pecel Kembang Turi, Roti Organik, Sate Klathak Sumber: http://www.blogasianfood.com

7. Museum (mewakili Nilai Keunggulan Seni Tradisi)

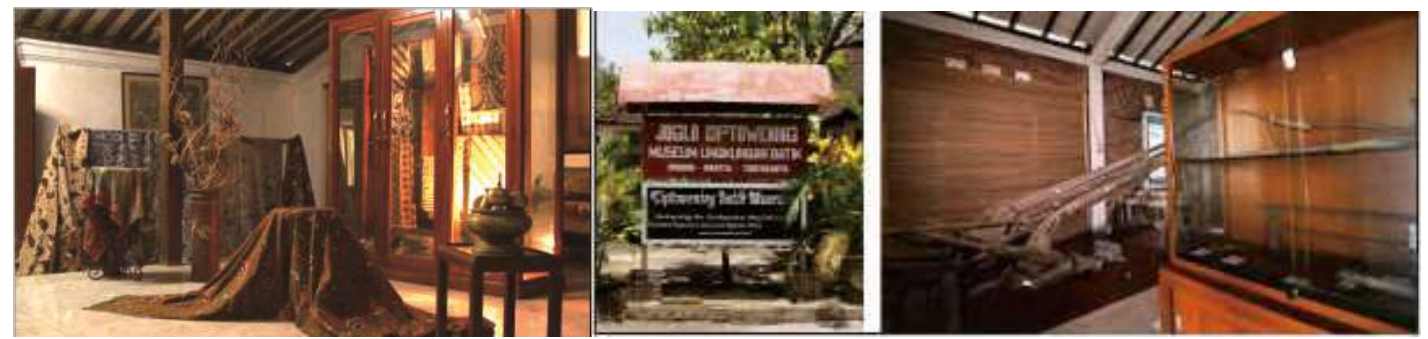

Gambar 7. Museum Batik Joglo Ciptowening, Museum Tani

Sumber: http://www.caritempatwisata.com

Pertanyaan terakhir pada kuesioner berupa pertanyaan kualitatif untuk mengetahui alasan responden memilih suatu destinasi tertentu. Pertanyaan ini berbentuk pertanyaan terbuka (open-ended) sehingga responden dapat menuliskan pendapatnya secara leluasa.

Data kuantitatif mengenai tempat yang ingin dikunjungi kemudian diolah menggunakan metode analisis distribusi. Data kualitatif mengenai alasan memilih para responden diolah menggunakan metode content analysis dan analisis distribusi. 


\section{HASIL DAN PEMBAHASAN}

Pada tahap analisis kuantitatif, dilakukan analisis distribusi untuk mengetahui frekuensi dipilihnya setiap destinasi. Analisis distribusi ini menghasilkan nilai yang menunjukkan destinasi mana yang paling banyak dipilih oleh responden

Destinasi yang paling banyak dipilih responden adalah Tempat Wisata Alam dengan perolehan sebanyak 61 suara (24\%). Destinasi dengan peroleh terbawah adalah pilihan kunjungan untuk melihat Bangunan Arsitektur Vernakular dengan perolehan 20 suara (8\%). Terdapat tiga destinasi yang secara signifikan banyak dipilih oleh responden, yaitu Tempat Wisata Alam, Tempat Kuliner, dan Kompleks Pemakaman Raja Mataram.

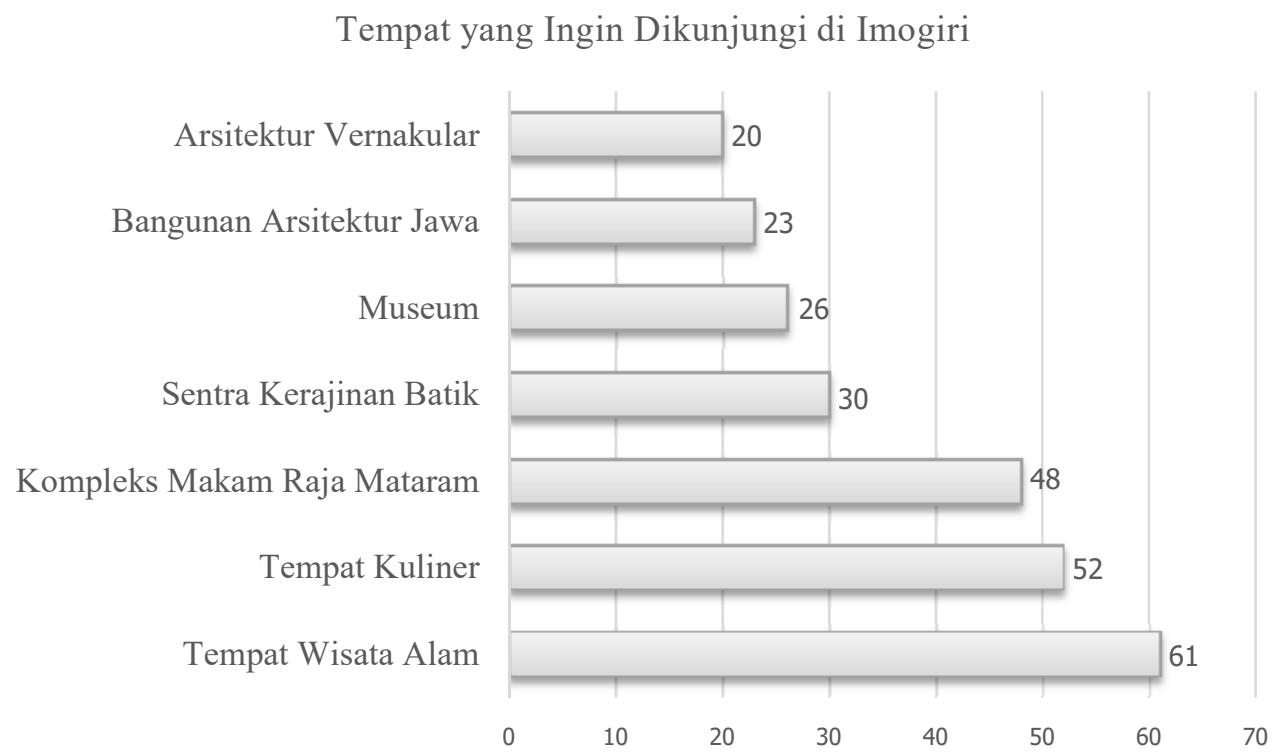

Gambar 8. Hasil Analisis Distribusi untuk Pertanyaan terkait Destinasi Sumber: Analisis Penulis, 2017

Meski Imogiri dikenal sebagai lokasi Kompleks Makam Raja Mataram dan sentra kerajinan batik, rupanya bagi masyarakat awam, destinasi yang paling ingin dikunjungi adalah tempat wisata alam dan wisata kuliner

Tingginya minat masyarakat untuk mengunjungi tempat wisata alam merupakan kabar baik bagi kelangsungan pariwisata pada suatu pusaka saujana karena hal ini dapat mendorong semua pihak untuk menjaga kelestarian alam yang merupakan komponen utama dalam suatu kawasan pusaka saujana. Temuan ini sejalan dengan konsep pariwisata pusaka dimana kegiatan pariwisata bertujuan mendukung pelestarian (Cahyadi, 2009). 
Untuk tahap analisis konten (content analysis), dilakukan open coding atau tahapan untuk mengidentifikasi kata-kata kunci dari data teks yang diperoleh. Contoh open coding dari komentar responden mengenai alasan memilih destinasi dapat dilihat dalam kutipan dari hasil kuesioner di bawah ini.

"Karena ingin menghilangkan kepenatan di kota dan aktivitas sehari-hari” (Pegawai Swasta) "Saya tertarik dengan sejarah melalui ziarah ke makam dan pesona alam yg menarik" (Pegawai Swasta)

Berdasarkan sampel deskripsi tersebut, didapatkan beberapa kata kunci dari alasan seseorang berkunjung yakni "melepas kepenatan/refreshing". Kemudian pada sampel berikutnya diperoleh kata kunci "ziarah", "belajar sejarah", "suasana alam".

Setelah open coding, dilakukan pengelompokan kata-kata kunci (axial coding) untuk menjadi kategori. Terdapat total lima kategori alasan berkunjung ke Imogiri. Kelima kategori ini kemudian dianalisis frekuensinya menggunakan analisis distribusi untuk mengetahui jawaban yang paling dominan.

Tabel 1. Kategori Motivasi yang Melatarbelakangi Kunjungan Wisata di Pusaka Saujana Imogiri

\begin{tabular}{|c|c|c|c|c|c|}
\hline \multicolumn{2}{|c|}{ KATEGORI } & \multirow{3}{*}{\begin{tabular}{l}
\multicolumn{1}{c}{ KATA KUNCI } \\
belum pernah \\
refreshing
\end{tabular}} & \multicolumn{2}{|c|}{ KATEGORI } & \multirow{2}{*}{$\begin{array}{r}\text { KATA KUNCI } \\
\text { menikmati budaya }\end{array}$} \\
\hline \multirow{6}{*}{1} & \multirow{6}{*}{$\begin{array}{l}\text { Motivasi } \\
\text { Internal }\end{array}$} & & \multirow{4}{*}{3} & \multirow{4}{*}{$\begin{array}{l}\text { Kegiatan } \\
\text { Budaya }\end{array}$} & \\
\hline & & & & & Ziarah \\
\hline & & $\begin{array}{l}\text { menambah } \\
\text { wawasan/pengalaman }\end{array}$ & & & $\begin{array}{l}\text { melihat elemen } \\
\text { arsitektur }\end{array}$ \\
\hline & & penasaran & & & $\begin{array}{l}\text { melihat koleksi } \\
\text { museum }\end{array}$ \\
\hline & & melihat perkembangan & \multirow{6}{*}{4} & \multirow{6}{*}{$\begin{array}{l}\text { Kegiatan } \\
\text { Rekreasi }\end{array}$} & menikmati alam \\
\hline & & ada acara/terpaksa & & & mencicipi kuliner \\
\hline \multirow{5}{*}{2} & \multirow{5}{*}{$\begin{array}{l}\text { Karakteristik } \\
\text { Tempat }\end{array}$} & menarik & & & membeli kerajinan \\
\hline & & suasana alam & & & tamasya \\
\hline & & populer & & & Berfoto \\
\hline & & $\begin{array}{l}\text { wisata beragam \&family } \\
\text { friendly }\end{array}$ & & & olahraga \\
\hline & & artistik \& bagus untuk foto & 5 & Kegiatan & belajar budaya \\
\hline
\end{tabular}




\begin{tabular}{|c|c|c|c|}
\hline KATEGORI & KATA KUNCI & KATEGORI & KATA KUNCI \\
\hline & bersejarah & Edukasi & belajar sejarah \\
\hline & makanan enak \& khas & & belajar arsitektur \\
\hline & udara sejuk & & belajar falsafah hidup \\
\hline & edukatif & & $\begin{array}{l}\text { belajar makanan } \\
\text { organik }\end{array}$ \\
\hline
\end{tabular}

Sumber: Analisis Penulis, 2017

Hasil analisis distribusi alasan responden berkunjung ke Imogiri dapat dilihat pada Gambar 9. Diperoleh informasi bahwa alasan paling dominan dariresponden untuk berkunjung ke Imogiri adalah karena ingin melakukan kegiatan rekreasi dengan perolehan nilai 48 (34\%). Jawaban dengan frekuensi sangat kecil adalah kegiatan budaya dengan nilai 12 (8\%).

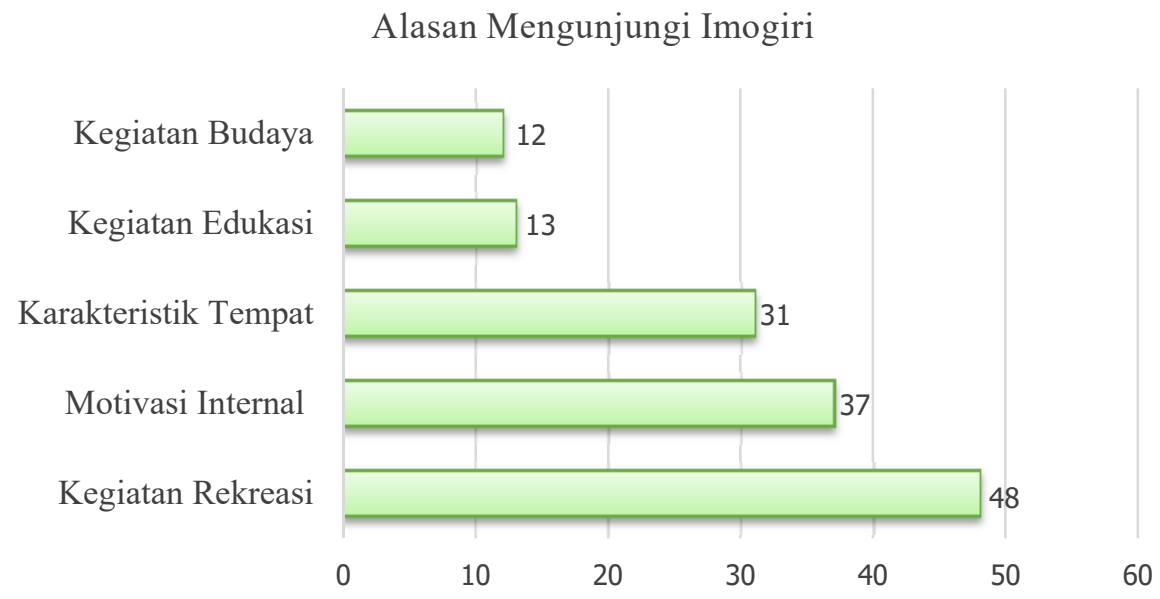

Gambar 9. Analisis Distribusi Alasan Berkunjung

Sumber: Analisis Penulis, 2017

Dari tanggapan responden, diketahui bahwa kegiatan rekreasi yang paling banyak dilakukan oleh pengunjung adalah kegiatan menikmati alam dengan perolehan nilai 22 (48\%). Kegiatan rekreasi dominan kedua yang dilakukan oleh pengunjung adalah kegiatan mencicipi kuliner dengan nilai 17 (35\%). Kedua kegiatan tersebut merupakan dua kegiatan rekreasi dengan perolehan paling signifikan. Kegiatan rekreasi lainnya dengan nilai relatif kecil adalah kegiatan membeli kerajinan, tamasya, berfoto serta berolahraga. 


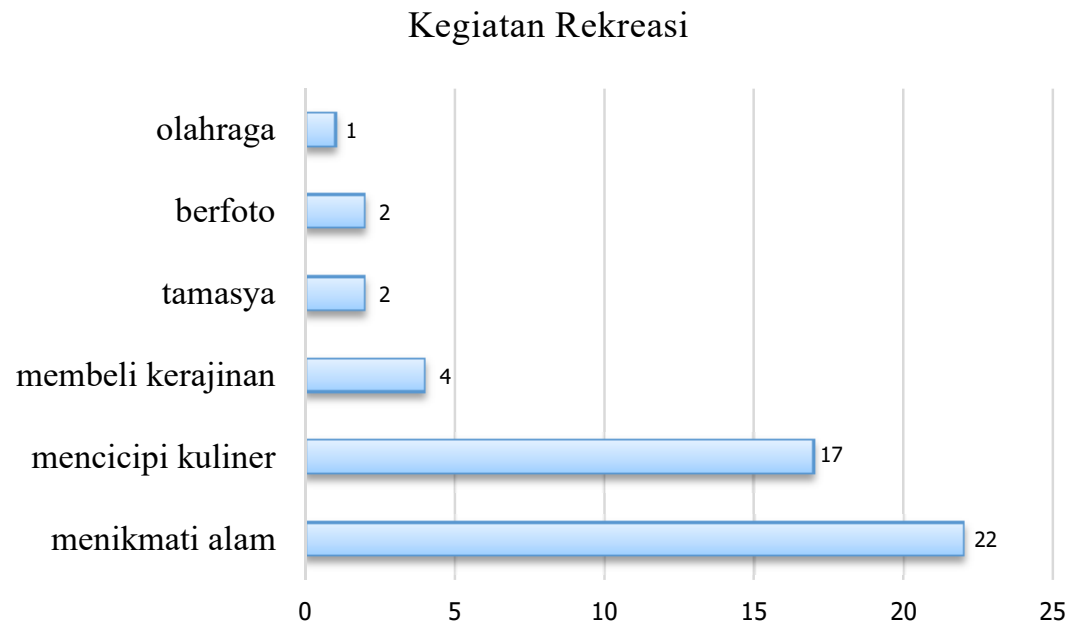

Gambar 10. Analisis Distribusi Kata Kunci untuk Kategori Kegiatan Rekreasi

Sumber: Analisis Penulis, 2017

Faktor kedua yang menjadi latar belakang kunjungan orang ke Imogiri adalah karena adanya motivasi internal atau motivasi dari diri pengunjung itu sendiri. Motivasi utama seseorang ingin mengunjungi tempat tertentu di Imogiri adalah karena belum pernah mendatangi tempat tersebut sebelumnya. Alasan ini merupakan alasan dominan dengan perolehan nilai 14 (37\%). Motivasi lain yang mendorong wisatawan untuk berkunjung adalah motivasi untuk refreshing, menambah wawasan dan pengalaman, penasaran, ingin melihat perkembangan, dan alasan dengan persentase terkecil adalah karena ada acara atau terpaksa.

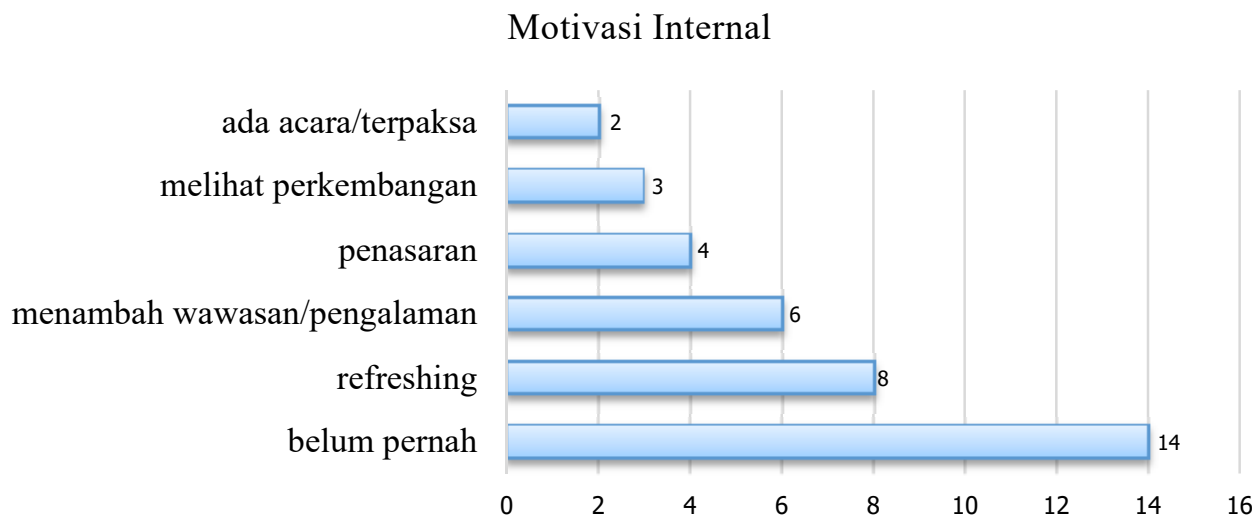

Gambar 11. Analisis Distribusi Kata Kunci untuk Kategori Motivasi Internal Sumber: Analisis Penulis, 2017 
Karakteristik tempat merupakan alasan terbanyak ketiga yang mendorong orang untuk berwisata ke Imogiri. Tempat dengan suasana yang menarik adalah karakter tempat yang disukai oleh sebagian besar responden. Karakteristik tempat berikutnya yang memperoleh nilai signifikan adalah tempat dengan pemandangan alam yang indah. Setelah kedua karakter tersebut alasan yang dikemukakan oleh responden terkait karakteristik tempat adalah tempat yang poluler, menawarkan wisata yang beragam dan bisa dinikmati seluruh keluarga, artistik dan bagus untuk foto, bersejarah, udaranya sejuk, dan memiliki nilai edukatif.

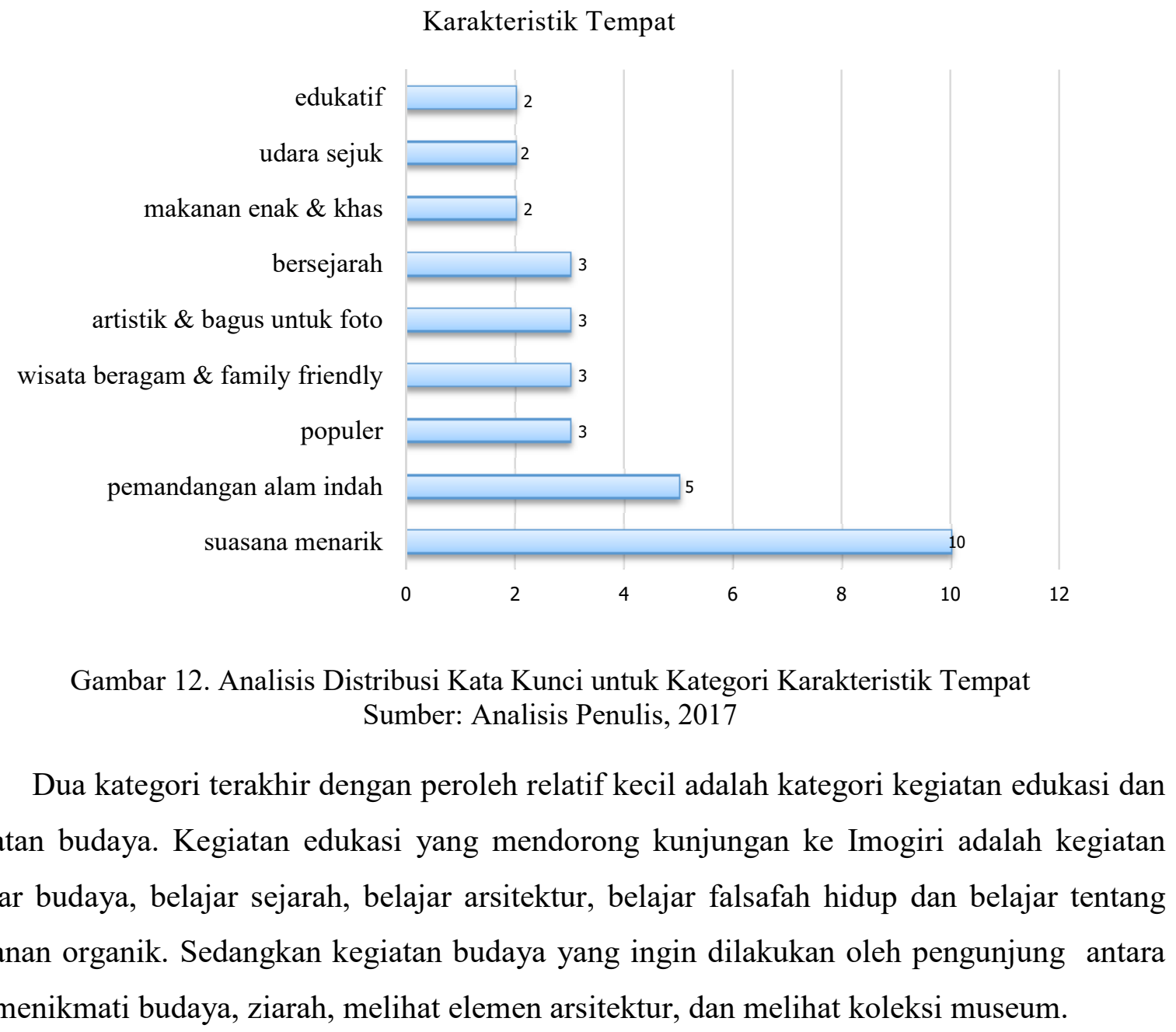

Fitria Puspita Rani, Hanson E. Kusuma, Athina Ardhyantol160 Pariwisata Pusaka : Destinasi Dan Motivasi Wisata ... 


\section{Kegiatan Edukasi}

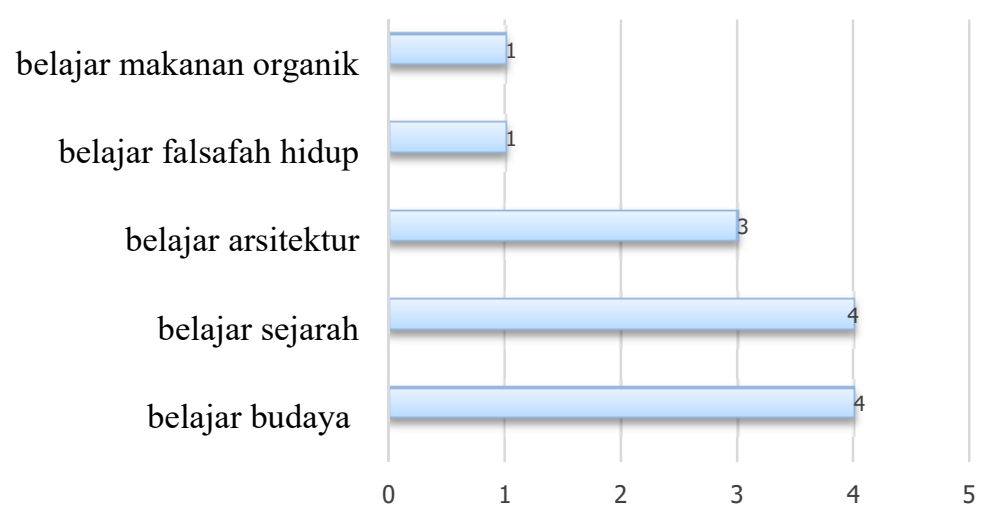

Gambar 13. Analisis Distribusi Kata Kunci untuk Kategori Kegiatan Edukasi Sumber: Analisis Penulis, 2017

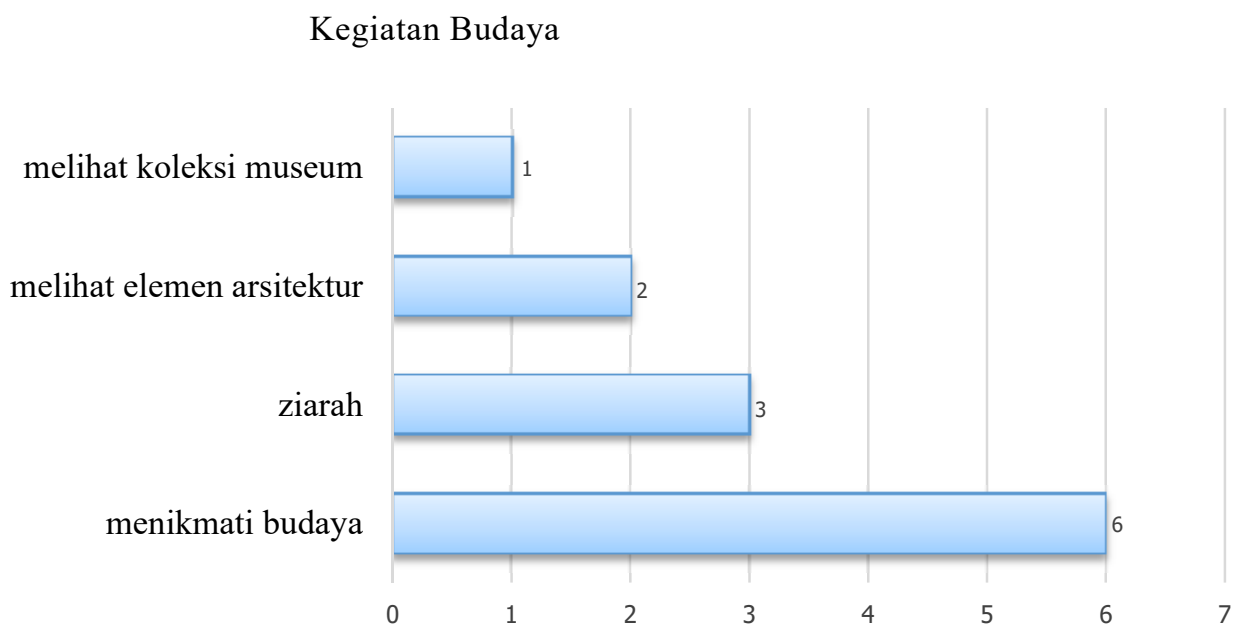

Gambar 14. Analisis Distribusi Kata Kunci untuk Kategori Kegiatan Budaya Sumber: Analisis Penulis, 2017

\section{KESIMPULAN DAN SARAN}

\section{A. Kesimpulan}

Di antara beberapa lokasi yang dianggap mewakili Imogiri sebagai sebuah Pusaka Saujana dan dapat mendukung kegiatan pariwisata pusaka, destinasi yang paling diminati untuk dikunjungi adalah tempat wisata alam, tempat kuliner, dan Kompleks Pemakaman Raja. 
Kondisi ini menggambarkan bahwa pariwisata di Pusaka Saujana Imogiri cenderung lebih diminati pada pusaka alamnya dibanding pusaka budayanya.

\section{B. Saran}

Tingginya minat berkunjung ke tempat wisata alam sejalan dengan sejalan dengan visi pariwisata pusaka yang bertujuan untuk melestarikan alam. Motivasi yang melatarbelakangi kunjungan wisatawan ke Imogiri adalah keinginan untuk melakukan kegiatan rekreasi, adanya motivasi internal serta faktor karakteristik tempat.

Penelitian serupa sebaiknya juga dilakukan di lokasi lain yang memiliki potensi pusaka saujana untuk dapat lebih memahami potensi pariwisata pusaka saujana di seluruh Indonesia. Selain itu, penelitian terkait motivasi, karakter tempat dan kegiatan sebaiknya juga dilakukan untuk mengetahui keterkaitan antar faktor-faktor tersebut.

\section{DAFTAR PUSTAKA}

Cahyadi, R. (2009). Pariwisata Pusaka: Masa Depan bagi Kita, Alam dan Warisan Budaya Bersama. Jakarta: UNESCO.

Creswell, J.W. (2008). Research Design: Qualitative, Quantitative, and Mixed Methods Approaches. California: Sage Publications, Inc.

Groat, L. \& Wang, D. (2002). Architectural Research Methods. New York: John Wiley \& Sons. Inc.

Dinas Pekerjaan Umum, Perumahan, dan Energi dan Sumber Daya Mineral Daerah Istimewa Yogyakarta. (2014). Rencana Induk Kawasan Budaya Perkotaan Yogyakarta 2014-2034. Yogyakarta: Dinas PU.

Dinas Agraria dan Tata Ruang / Badan Pertanahan Nasional Daerah Istimewa Yogyakarta. (2016). Rencana Terpadu dan Jangka Menengah Kawasan Strategis Keistimewaan 2016. Yogyakarta: ATR/BPN DIY.

Taylor \& Lennon. (2012). Managing Cultural Landscape. Oxon: Routledge

Jaringan Pelestarian Pusaka Indonesia dan International Council on Monuments and Sites. 2003. Piagam Pelestarian Pusaka Indonesia “Merayakan Keanekaragaman”. Ciloto: JPPI \& ICOMOS. 
Keliwar, S. \& Nurcahyo, A. (2015). Motivasi dan Persepsi Pengunjung terhadap Obyek Wisata Desa Budaya Pampang di Samarinda. Samarinda: Jurnal Manajemen Resort dan Leisure Vol. 12. No. 2, Oktober 2015.

Dwiputra, Roby. (2013). Preferensi Wisatawan terhadap Sarana Wisata di Kawasan Wisata Alam Erupsi Merapi. Jakarta: Jurnal Perencanaan Wilayah dan Kota, Vol. 24 No. 1, April 2013.

Sahara, F. N. A., Iqbal, M., \& Sanawiri, B. (2016). Analisis Motivasi Berkunjung Wisatawan Dan Tingkat Pengetahuan Wisatawan Tentang Produk Industri Kreatif Sektor Kerajinan (Studi Pada Wisatawan Domestik Di Kota Batu, Jawa Timur). Jurnal Administrasi Bisnis, 35(2), 146-154.

Dwi Atma, O. (2017). Sejarah Berdirinya Makam Imogiri antara Naskah Serat Pengetan Jasan Dalem Para Nata dengan Cerita Rakyat"(Kajian Intertekstual). Thesis. Semarang : Universitas Diponegoro. 